\title{
Strategic planning for dairy cattle: SWOT analysis applied to a property of a farmers' association in Dracena, São Paulo state, Brazil
}

\author{
Planejamento estratégico da bovinocultura leiteira: análise SWOT aplicada a uma \\ propriedade associativa de Dracena, SP
}
Planification stratégique des bovins laitiers: analyse SWOT appliquée à une propriété associative de Dracena, São Paulo, Brésil

La planificación estratégica del ganado lechero: análisis SWOT aplicado a una propiedad asociativa de Dracena, São Paulo, Brasil

\author{
Omar Jorge Sabbag* \\ (sabbag@agr.feis.unesp.br) \\ Sílvia Maria Almeida Lima Costa* \\ (smalcost@agr.feis.unesp.br)
}

Recebido em 17/02/2014; revisado e aprovado em 15/07/2014; aceito em 23/08/2014

DOI: http:/ / dx.doi.org/10.1590/1518-70122015109

\begin{abstract}
The sector of milk production in Brazil is very heterogeneous (high-tech in large scale X family properties). This study aimed to develop a diagnostic as a basis for a strategic plan to face the challenges inherent in operating a dairy farm in property of a farmers' association in Dracena, São Paulo, Brazil. It was observed that the association needs a more efficient guidance in the marketing, production and finance areas, not to compromise the search for new markets and continued growth in activity.

Key words: Milk. Rural management. SWOT analysis.

Resumo: O setor de produção de leite no Brasil é muito heterogêneo (alta tecnologia em grande escala X propriedades familiares). Este estudo teve como objetivo desenvolver um diagnóstico que sirva de base para um planejamento estratégico frente aos desafios inerentes a exploração leiteira de uma propriedade associativista no município de Dracena, SP. Observou-se que a associação precisa de uma orientação mais eficiente nas áreas mercadológica, de produção e finanças, para não comprometer a prospecção de novos mercados e o crescimento contínuo da atividade. Palavras-chave: Leite. Gestão rural. Análise SWOT.

Résumé: Le secteur de la production laitière au Brésil est très hétérogènes (de haute technologie à grande échelle $X$ propriétés de la famille). Cette étude visait à développer un diagnostic de base à un plan stratégique pour relever les défis inhérents à l'exploitation d'une ferme laitière propriété associative dans la commune municipalité de Dracena, São Paulo, Brésil. Il a été observé que l'association a besoin d'une orientation plus efficace dans le domaines du marketing, de la production et de la finance, de ne pas compromettre la recherche de nouveaux marchés et une croissance continue de l'activité.

Mots-clés: Lait. Gestion rurale. L'analyse SWOT.

Resumen: El sector de la producción de leche en Brasil es muy heterogéneos (de alta tecnología de gran escala X propiedades de la familia). Este estudio tuvo como meta desarrollar un diagnóstico como base de un planificación estratégico para hacer frente a los desafíos inherentes a la operación de una propiedad asociativa en el municipio Dracena, São Paulo, Brasil. Se observó que la asociación necesita una orientación más eficiente en las áreas de marketing, producción y finanzas, para no poner en peligro la búsqueda de nuevos mercados y el crecimiento continuo de la actividad.

Palabras clave: Leche. Gestión de las zonas rurales. Análisis SWOT.
\end{abstract}

\section{Introduction}

The agroindustrial complex of milk has strategic importance in the productive list of agribusiness, given its economic and social relevance. Among the factors relevant to the social dimension, common sense easily recognizes the milk (and some dairy products) as food whose presence one cannot ignore the composition of the human diet.
To the productive sector, from nineties the milk production chain in Brazil was favored by the reduction of public interference in markets, technological gains earned in technical and organizational innovations that became more able to face foreign competition promoted by market opening (factor that impacts caused in the 90's) and was favored with the establishment of norms and standards of quality (ANUALPEC 2013; SCHUBERT;

* Universidade Estadual Paulista Julio de Mesquita Filho (UNESP), Campus de Ilha Solteira, SP, Brasil. 
NIERDELEM, 2011; CHADDAD, 2007; FARINA et al., 2005). This set of structural changes resulted in a gradual increase in national milk supply; the period 2007-2013 the offer presented a growth rate of $4.3 \%$ per year, and only the estimated production in the year 2013 amounted to 35 billion liters, 35\% more than the 26 billion accounted in 2007, according to data from Brazilian Institute of Geography and Statistics.

Despite the favorable outcome, the milk production sector in Brazil is very heterogeneous. While holding on more present throughout the country, is responsible for the employment of a significant proportion of the workforce in family systems, these in turn are home to a plurality of heterogeneous systems of milk production (NORDER, 2006; SCHUBERT; NIERDELEM, 2009).

In this set plural, some farmers opt for a model based on intensive use of industrial feed, pharmaceuticals and preference for more productive breeds in order to increase productivity and production scale, while others lead to milk production with alternative strategy focused on reducing accompanied the running costs of inputs played on the unit itself, in non-specialized systems managed by little educated producers that consequently have a small capacity to assimilate new and more efficient production processes (EMBRAPA, 2004).

In summary it can be argued that, while strongly grounded in the small family production commonly represented by cooperative arrangements (associations or producer's cooperatives) the competitiveness of the sector has to face serious challenges: responding to the legal regulations that establishes standards of quality in production processes and the final product; face the difficulties of dealing with a sector of industrial processing (dairy) in market concentration process with large corporations leading agroindustrial processing transactions, thus setting an oligopoly industry and therefore, more power to negotiate prices.

This context investigated the need for improved decision making and planning, a productive sector already struggling with a lack of flexibility and low financial capacity, as highlighted Jank and Galan (1998). To the knowledge of reality in which they live (market structure, human resources, technological and financial alternatives, among others), it is necessary to develop efficient management mechanisms. Among these, there is the development of a strategy to assist in decision making, establishing the actions to be followed to maximize the goals of the producers and the association. The strategies should be based on performance evaluation tools in order to assist the process of decision making and remain competitive in the market (PETRI, 2005).

Among the possible strategies, has been raising environmental aspects based on the indicators of threats and opportunities, keeping in mind that they have to be methodically aligned in order to make the managerial decision systems dynamic mainly when it comes to the formulation, adaptation and implementation of actions defined by the execution of the strategic plans.

For Colenghi (2007), strategic planning is achieved from the concentrated effort of the company management and based on its mission and business, taking into consideration the survey, analysis and proposition of solutions related to an action plan that aims to guarantee the desired quality by the organization clients, reduce uncertainty, increase the degree of organizational success and establish an effort within the organization, according to Certo e Peter (2005).

According to Wright et al. (2000), strategic administration is the greatest challenge for administrators because the management of organizations becomes more and more challenging due to the environmental dynamics and the speed of changes, making constant adaptation needed.

Then, the phases for the elaboration of the strategic planning from the strategic process models presented by Colenghi (2007), Bethlem (2004), Kotler (2000), Wright, Kroll and Parnell (2000), are: definition of the business and the organization mission, analysis of the internal and external environments, planning of scenarios, formulation of strategies, elaboration of the action plan, implementation of the strategies, feedback and control. To Oliveira (2009), for an analysis of the opportunities (markets to 
explore and enjoy the resources), as well as threats, considering under competitive with their strengths and weaknesses environment, in order to lead to the choice of the purposes from existing scenarios, being confined for the present study.

Thus, this study aims to develop a diagnostic of the productive structure and market as a basis for developing a strategic plan to face the challenges inherent in operating a dairy farm in property of a farmers' association in Dracena, São Paulo/ Brazil.

Observing the risks, uncertainties and challenges involved in milk production and markets, is characterized the importance of a study focused on environmental analysis in a associative property, from an assessment of production operations, with the prospect der scenarios for developing strategies for the activity.

\section{Materials and Methods}

A diagnosis was done to characterize the case study milk production in Dracena, west São Paulo State/Brazil so that the milk production of the studied farmers' association can be understood. The case study focuses on understanding the dynamics present within single settings; can involve either single or multiple cases, and numerous levels of analysis (YIN, 1984).

Dracena has a 50,000 ha area and 30,000 ha is cultivated as pasture with a mixed herd of 39,677 head of cattle, a productivity of 911.63 liters/head/year, in more than 400 productive farms (EDR-Dracena, 2006; LUPA, 2008).

After that, the organizational evaluation tool used in this study (SWOT analysis), prospecting scenarios according to the opportunities and threats of the studied organization when compared to the external environment. Thus, a questionnaire was developed and applied to 41 farmers, who were responsible for primary research data, using different steps of the analysis for the internal/external environment. This study was classified as exploratory, descriptive and bibliographical. The research systematized the main characteristics of the sample population, as well as field survey in order to directly question the people involved whose behavior you want to know.

The main focus of the research summarized in diagnosing the productive and market it serves the association environment, strengths and weaknesses points and potential threats in the environment, related to the risk of the activity, with the purpose of directing possible strategies to maximize opportunities and mitigate limitations imposed on producers associated with performance limit defined for values with scores lower than 7 scores on the SWOT matrix.

The set of resources allocated in the organization (internal resources) and that are controlled by the organization in order to reach its objectives, include physical, human, logistic, operational, financial and marketing resources; they are defined as the internal environment or micro environment (PORTER, 2002).

In order to diagnose the agricultural company, considering its potentialities in the management of internal resources, and to plan which future events may be contrary to market opportunities, it is necessary to assess the internal organization considering the main administration areas that correspond to production, marketing, human resources and finance.

The strong and weak points represent controllable variables, whereas the opportunities and threats represent noncontrollable variables by the company, making evident that the biggest problem is the controlled and non-controlled variables. Still, the manager will have to identify the solution to prevent weak points from causing serious problems for the company (OLIVEIRA, 2009). Therefore, SWOT analysis provides a very significant strategic orientation because, the technique is credited to Albert Humphrey and, according to Hill e Westbrook (1997), it allows:

- Eliminating weak points in the areas where the organization faces serious threats from the competition and unfavorable trends in business;

- Understanding the opportunities discovered from the strong points;

- Correcting the weak points in the areas where the organization sees potential opportunities; 
- Monitoring areas where the organization has strong points in order not to be surprised by future possible risks and uncertainties.

In the approach of the matrix between internal environment (strong/weak) and external environment (opportunity/threat), a diagnosis of the position of the organization can result in the following four distinct situations:

- Survival (weak points $x$ threats);

- Maintenance (strong points $x$ threats);

- Growth (weak points x opportunities);

- Development (strong points x opportunities).

The SWOT analysis resulted in a positioning map of the organization, characterizing its present situation (strong and weak points) in relation to the market. In this sense, the SWOT analysis should be constructed keeping in mind the specific objectives of the organization, which provides a starting point to find strategies to minimize and provide guidance to producers.

In this case, it is fundamental that there is an analysis of several aspects like the main organizational principles, evaluation criteria and information collection when the weak/ strong points of an agricultural organization are established - like the association of milk producers.

\section{Results and Discussion}

The Farmers' Association of Dracena, established in the town since 2003, has 200 members and 44 of them participate directly in the dairy cattle activity, producing 54,000 liter in the dry season and 80,000 liters in the rainfall season in a permanent yearly productive cycle in function of changing quantities and prices ( $\mathrm{R} \$ 0.60$ to $\mathrm{R} \$ 0.79 /$ liter).

The milk production with 4 expansion tanks and total capacity of 3,500 liters is directly commercialized with a dairy/ association in the region that evaluates the price based on offer and product quality (bonus or penalties to the producers).

Considering the SWOT analysis in the organization environment (specifically the farmers' association and the productive milk farms that were studied and that represent about $20 \%$ of the sampling), it was observed that some specificities presented critical points for a substantial growth of the group activity through the different market areas, production, administration, finance and human resources, as shown next.

Analyzing the market environment of the dairy farm, it is verified that quality and consequent standardization of milk is under development because of a program implemented by SEBRAE - Presidente Prudente/ Brazil (Figure 1) in 2008.
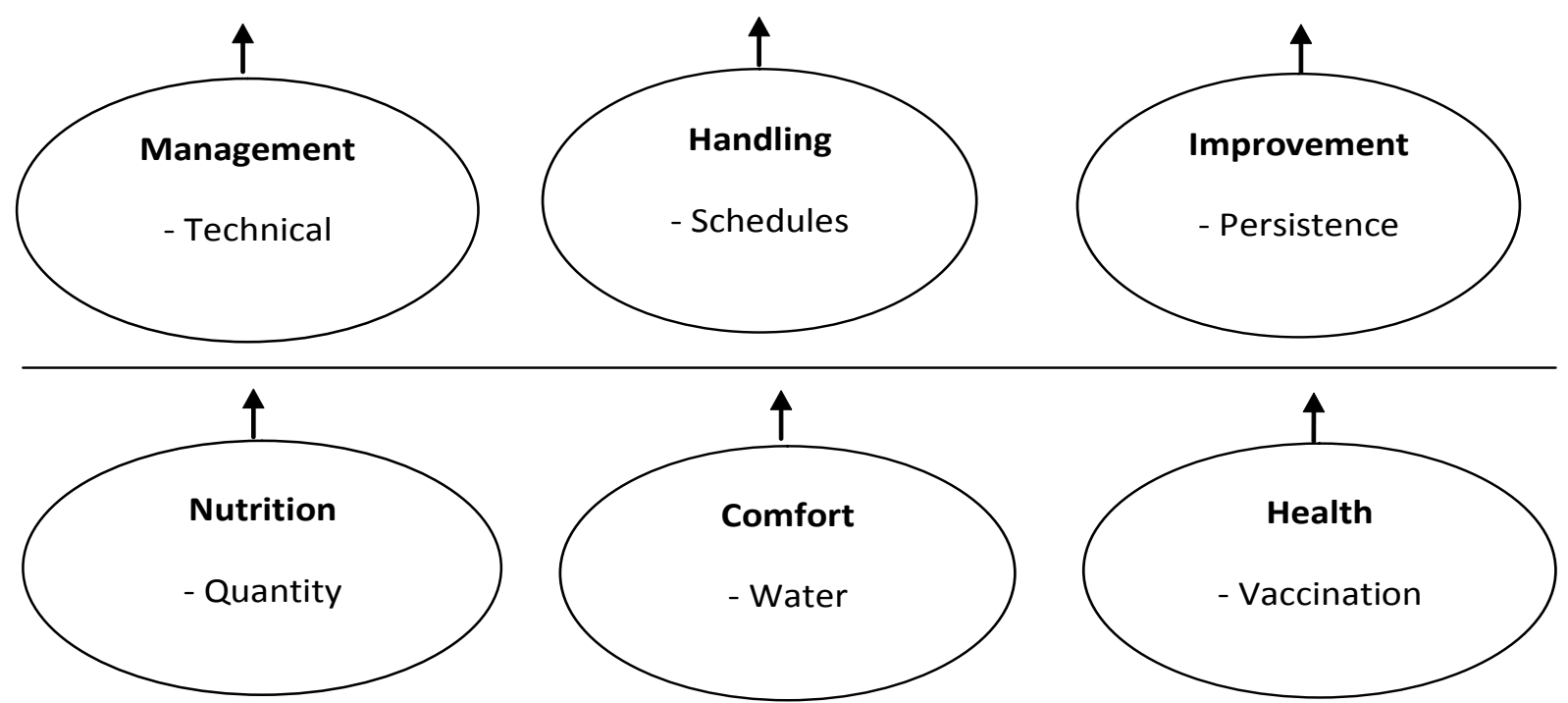

Figure 1 - Recommendation for a good performance: main steps in milk production. Source: SEBRAE/Instituto Aequitas (2008). 
The program has characterized 41 studied producers (Table 1) using the tank analysis (through milk collection by the "Clínica do Leite" - Esalq/USP) to analyze specific points of milk quality. The quality of the primary product increased from March to July, 2010.

Table 1 - Sampling of APRD producers in relation to the TCC (milk quality program), Dracena/ Brazil, 2010.

\begin{tabular}{|c|c|c|}
\hline TCC (total colony counting) x R\$ & MAR/2010 & JUL/2010 \\
\hline $\mathrm{TCC}=\mathrm{x} \mathrm{mil} \mathrm{CFU} / \mathrm{ml}$ & \multicolumn{2}{|c|}{41 producers } \\
\hline $0-100$ (R\$ 0.02/liter) & 5 & 31 \\
\hline $101-200$ (R\$ 0.01/liter) & 10 & 9 \\
\hline 201 - 500 (neuter) & 16 & 1 \\
\hline Over 501 (-R\$ 0.02) & 10 & - \\
\hline AVERAGE TCC & 525 & 60 \\
\hline
\end{tabular}

Source: survey data. (CFU/ $\mathrm{ml}=$ colony forming units.)

Due to these achieved positive results, APRD received more bonuses ( $\mathrm{R} \$ 0.02$ ) commercialized liter), and in the last evaluation only $2.4 \%$ of studied producers did not receive a bonus in this situation; it also shows a growth and concern in relation to the provision to the association.

As to the distribution, there is exclusivity in relation to the providing association; besides, part of the producers are also benefited with subside from the federal government (via CONAB and the Ministry of Agricultural Development) through a program of provision to public institutions considering an income of $\mathrm{R} \$ 3,500.00 /$ family/year, limited to a provision of 1000 liters/week.

A limitation to the market environment directly reflects the lack of product knowledge in the local and regional market, limiting the expansion of their commercialization because the buying association uses its own brand "Brancão" for the obtained raw material. This could be improved through the certification of the municipal inspection; this certification could allow the farm association to prospect new clients as well as to start making some dairy products using the produced milk (like fresh cheese and creamy cheese) in its facility.

Beyond this point, milk market is at structure oligopsonic; is a market form in which a market is dominated by a small number of buyers and there may be an acknowledged market leader which informally sets prices to which other buyers respond, and competitors feel compelled to match that price. In this region the company Brancão is the main buyer, followed by two other major companies.

As to the production, there are several limitations to the strict production control and the input use. In milk production, the obtained data in this study complement a study done by SEBRAE/Instituto Aequitas (2008), where producers showed that the pasture area is heterogeneous due to the different management applied to the production systems by the producers (Figure 2).

These discrepant results corroborate the need for safe livestock production systems, especially in light hygiene and health, thus contributing to the environmental health and safety food (BARROS et al., 2009).

The milk production/cow has a negative heterogeneous feature, corroborating the management heterogeneity. According to Anualpec (2013), the national average is 5.62 $1 /$ cow / day; the state of Ceará / Brazil has the greatest production per cow (12.34 1/cow/ day) and the state of Sao Paulo produces $4.981 /$ cow/day. Both show low productivity when compared to the European average of $171 /$ cow/day (FAO, 2004). 


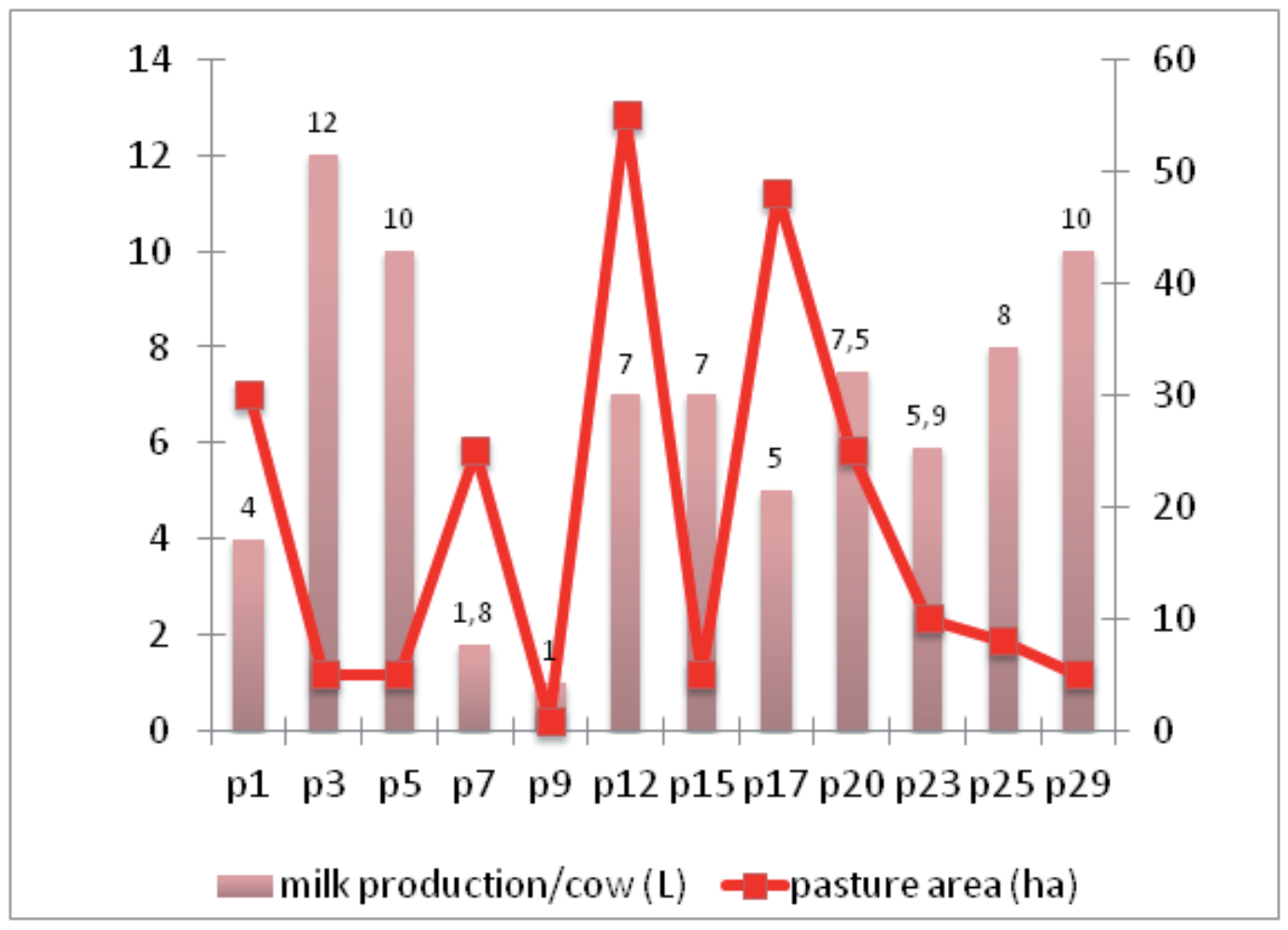

Figure 2 - Pasture area X milk production/cow, APRD.

Source: SEBRAE/Instituto Aequitas (2008).

Regarding the input acquisition (mineral salt, feed), there is a certain limitation in the joint purchase, which could contribute to minimize the production costs, because animal feeding constitutes one of the highest cost percentages during the productive cycle (on average 50 to $60 \%$ of the operational cost). The exception is the vaccination purchase and control (which is a legal obligation and imposition). This also results in some difficulties to achieve the objectives proposed by the farmers' association (mainly increasing the productive profitability), specially because of the absence of planning and organization of group activities.

A critical point in the production organization is seen in the absence of notes in daily controls of costs and incomes of the whole operational productive cycle, making a better administration of these utilized scarce resources, besides not managing the formation of prices established by the cooperative, verifying if they are enough to cover production costs and consequently resulting in the profit needed to maintain its activities.
Regarding the administration of APRD, the association membership has been growing continuously since 2003. In the milking activity, the relationship with the production consuming association is imposition $X$ reliable payment, that is, the price is pre-established according to the commercialized volume and product quality, considering the specific date for the payment and the (shared) distribution by the members.

It is important to notice that the administrative role of the association is to plan, organize, manage and control the activities, besides managing people that interrelate (with the production and market environments), guided toward a common objective which is the optimization of the company activities.

In finance, there is not a profitability prediction for the commercialized item because there is not a control of its expenses and incomes that are fundamental for the verification of profit and overturn of investments, disregarding the mobilized assets like vehicles and 10-year-old cooling tanks that are depreciated and shared by all 
members due to the creation of a replacement fund.

About human resources, there is good motivation among the members; however, there is also a lack of participation (union and interest) to improve productivity, considering a possible penalty imposed by some members who have not re-adapted to the legislation (MAP - Ministry of Agriculture and Livestock). An imposed limitation is the absence of a formal contract stating the duties and obligations in the statute characterizing members as small producers (not having a commitment with standardization) and not as potential small businesspeople for the regional agro business.
Another important characteristic is the small participation in training courses that would aggregate knowledge to the association and then reinforce group commitment to increase production and quality, including women's participation in the manufacturing of dairy products.

Because of obtained results, a spreadsheet with results from the utilized questionnaire (Table 2) was developed in order to identify the main internal characteristics of the association, relating the external organizational environment so that the simultaneous interference of both environments was considered for the studied organization.

Table 2 - SWOT analysis (weak and strong points), considering the internal and external environments of APRD, 2010.

\begin{tabular}{|c|c|c|c|c|}
\hline $\begin{array}{c}\text { Internal } \\
\text { Environment }\end{array}$ & Weak/strong points & $\begin{array}{c}\text { Value } \\
(\%)\end{array}$ & Overall evaluation & Score \\
\hline \multirow{2}{*}{ Market } & $\begin{array}{l}\text { Quality/product } \\
\text { standardization }\end{array}$ & 10 & Uniformity & 8 \\
\hline & Market acceptance & 10 & Consumer information & 5 \\
\hline \multirow{2}{*}{ Production } & Efficiency/Productivity & 10 & Technology and management & 7 \\
\hline & Cost structure & 10 & Spreadsheets & 0 \\
\hline \multirow[t]{2}{*}{ Administration } & Experience/ability & 20 & $\begin{array}{l}\text { Knowledge of administrative } \\
\text { routines }\end{array}$ & 8 \\
\hline & Teamwork & 20 & Cooperation & 7 \\
\hline \multirow{2}{*}{ Finance } & Investments (TIR, pay back) & 5 & Economic viability & 0 \\
\hline & Profitability & 5 & Economic analysis & 7 \\
\hline \multirow{3}{*}{ Human Resources } & Motivation & 5 & Incentives & 8 \\
\hline & Professional capacitation & 5 & Recycling & 5 \\
\hline & Control 100\% & 100 & Average & 6 \\
\hline $\begin{array}{c}\text { External } \\
\text { Environment }\end{array}$ & Opportunities/threats & $\begin{array}{l}\text { Value } \\
(\%)\end{array}$ & Overall evaluation & Score \\
\hline \multirow{3}{*}{ Legal political } & Labeling/packaging & 10 & Specification & 6 \\
\hline & Access to market/certification & 20 & Accessibility & 1 \\
\hline & Availability/input restriction & 15 & Resource management & 7 \\
\hline \multirow[t]{2}{*}{ Economic } & Unexpected expenses & 15 & Cost availability & 7 \\
\hline & Capital availability & 20 & New investments & 6 \\
\hline \multirow{2}{*}{ Socio-cultural } & Consume habits & 5 & Adaptability & 7 \\
\hline & Population concentration & 5 & Production flexibility & 7 \\
\hline \multirow{3}{*}{ Technological } & Sales/orders & 5 & Deliveries/income & 8 \\
\hline & Technological solutions & 5 & Productive capacity & 5 \\
\hline & Control $100 \%$ & 100 & Average & 5.6 \\
\hline
\end{tabular}

Source: survey data.

When evaluating the association in relation to the external environment (through SWOT), the following characteristics that could inhibit a better market participation (in the absence of MIS certification) were observed: - Prospecting new markets: while the associative group marketing milk commodity tra- ding new markets is restricted to changes in customer/supplier relationship, new buyers will be represented by operative dairy in an oligopoly market;

- The decision to gain competitiveness through the development of own brand accompanied by labeling and packaging for brand 
positioning in retail markets is limited by technological and managerial base, investments in improving this may represent an financial risk due to a possible pressure of established brands;

- Even with the restriction expressed by the pressure of established brands, the development of quality attributes of the milk produced, considering the existence of close relations between the producer group and the local society, the associative group has the opportunity to achieve better positioning in local marketing channels settling in short marketing circuits.

It can be observed that the weak/strong points had specific relative values due to the importance of each item (vector) in the organization, considering its influence degree in the market. Because of the analysis results (positioning map), Figure 3 shows the present situation of the association as a consequence of the opportunities and/or threats related to the producer's organization.

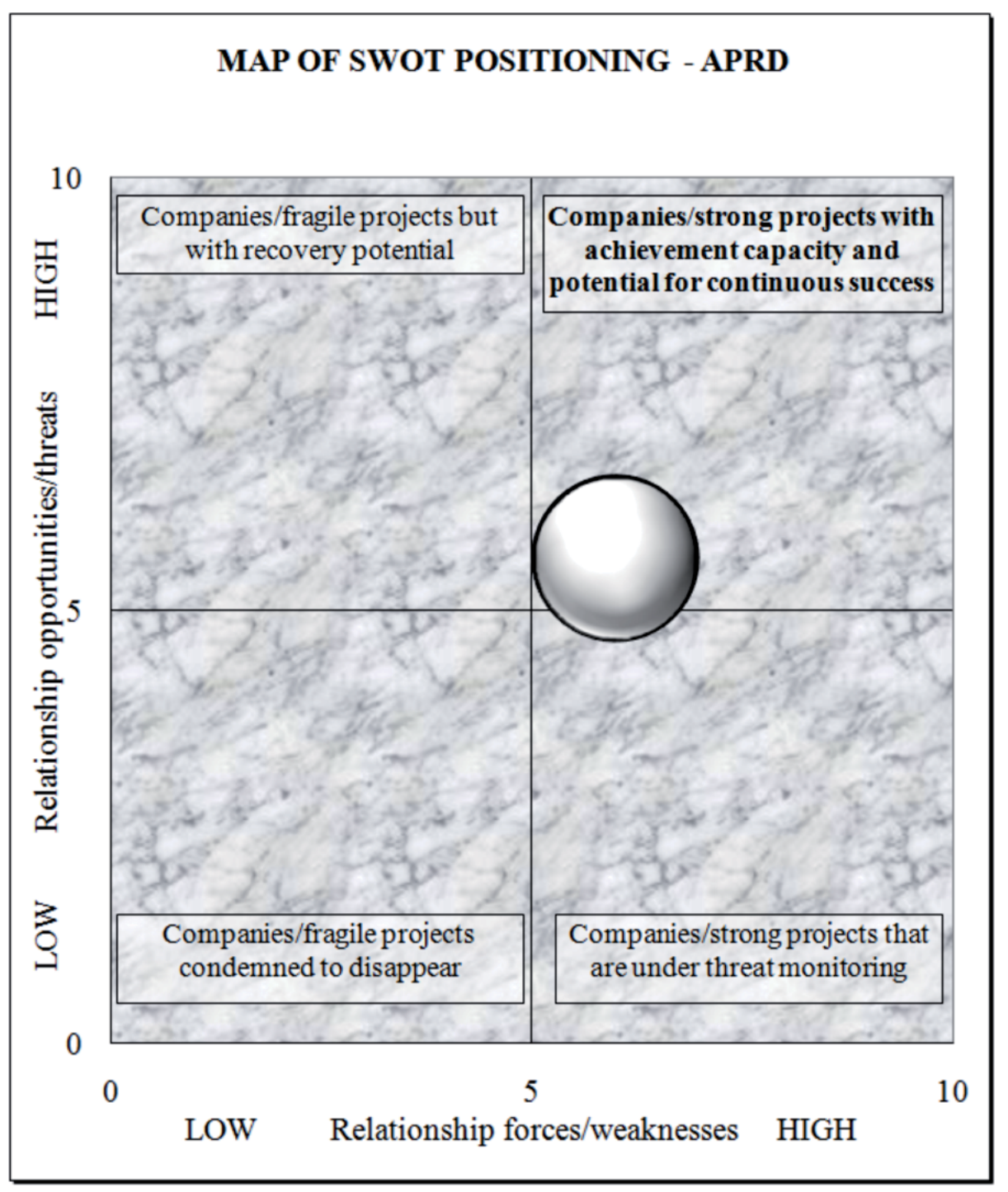

Figure 3 - Map of SWOT positioning - APRD, 2010.

With the identification of strengths and weaknesses points, it is necessary targeting strategies, especially for low value of some scores that stood out for the internal environment (with a mean score of 6), which directly reflected the main macro variables (political-legal, economic and technological) indicated with score 5.6, corresponding to main threats. Thus, as Alday (2000) points outs, the strategic planning must be seen as 
a dynamic management tool that contains anticipated decisions about the performance of the organization to meet its mission.

For the marketing aspect and improving the quality of raw material, it is recommended to adopt a differentiation strategy, with the implementation of a certification program, which ensures generate greater added to the price paid to the producer by the possibility of diversification of dairy products.

In this sense, Digiovani (2006) infers that the certification process can be understood as a guarantee that the product meets the specifications of pre-established and recognized quality, to meet the demands required by consumers, ensuring better participation of raw materials (in this case, milk) to consumer.

In this context, it can be verified that the members are in the improvement quadrant, which makes it possible for them to continue their activity as long as there is some more efficient orientation to obtain the MIS - Municipal Inspection System - approval (which is usually limited by the municipal administration itself during the inspection and certification) as there is a strong threat in the prospecting of new markets and continuous growth of the activity.

For the aspect of production/finance, there are some additional to emphasize, among them the need for collective organization to support the joint purchase of inputs, in order to reduce operating costs, as well as guidance for data collection among themselves producers, which make them vulnerable to economic outcomes, because they don't write down the main technical coefficients of production.

Finally, with respect to human resources aspect, disinterest and the low level of qualification among members also contribute to the limitation in relation to the outside environment. In this case, should work with joint actions of planning and organization, through a participatory rural appraisal (PRA), in order to identify the main causes that adhere to the main problem in the production environment, with greater specificity to the production (quality and certification) and profitability. Thus, the PRA aims to develop research processes from conditions and possibilities of the participants, based on their own concepts and criteria of explanation. Instead of confronting people with a list of previously formulated questions, the idea is that participants analyze their own situation and value different options to improve it (VERDEJO, 2006).

In summary, the scenario prospected for the dimensions of external environmental analysis for the production of milk for the association in study, the use of production technologies and information thereby increase milk quality as well as increased productivity and consequent profitability. However, even in small proportions, continue informal trade. The health legislation will tend to be more demanding, featuring a threat to producers who do not fit, creating an opportunity for others to become more competitive.

\section{Conclusions}

Based on the theoretical reference of an internal analysis of an organization (in this case, a milk producers association), the elaboration of a diagram that can illustrate the competitiveness capacity is an essential condition to predict the exhausting impact of the sector. In this sense, through the knowledge of technological production standards that are part of their behavior, will be able to meet its actual and potential capacity, that the planning activity, requires the creation of strategies to leverage this productive sector, characteristic that the activity itself becomes essential to anticipate decisions in a dynamic environment in the Brazilian economy, which is agribusiness.

Specifically for the weak points in milk production, there is need for change with greater expressiveness in production and finance, mainly due to the heterogeneity of the output and the lack of control in relation to costs and profitability to the production system, together with the need joint training among producers linked to the association, to maximize opportunities in relation to the external environment.

Because of the importance of strategically planning a rural activity, as milk exploration in the referred case, noted also that the importance of identifying strengths and weaknesses more clearly defined shape 
and provides a resource optimization, allowing the market to turn threats into business opportunities.

\section{References}

AGRÍCOLA BETHLEM. Estratégia empresarial: conceitos, processo e administração estratégica. 5. ed. São Paulo: Atlas, 2004. 346p.

ALDAY, Hernan E. Contreras. O planejamento estratégico dentro do conceito de administração estratégica. Revista FAE, Curitiba, v. 3, n. 2, p. 9-16, maio/ago. 2000.

ANUALPEC 2013. Anuário da pecuária brasileira. São Paulo: FNP, 2013. 357p.

BARROS, Ludmilla Santana Soares et al. Qualidade microbiológica e físico-química do leite de cabra. Magistra, v. 21, n. 3, p. 146-153, 2009. Disponível em <http:/ / www.ufrb.edu.br/magistra/2000-atual/ volume-21-ano-2009/numero-3-jul-a-set/512-qualidade-microbiologica-e-fisico-quimica-do-leite-de-cabra>. Acesso em: 5 jun. 2012.

CERTO, Samuel; PETER, John. Administração estratégica. São Paulo: Mackron Books, 2005.

CHADDAD, Fábio Ribas. Cooperativas no agronegócio do leite: mudanças organizacionais e estratégicas em resposta à globalização. Organizações Rurais e Agroindustriais, v. 9, p. 69-78, 2007.

COLENGHI, Vitor Mature. O \& Me qualidade total: uma integração perfeita. 3. ed. Uberaba, MG: V.M. Colenghi, 2007. 275p.

DIGIOVANI, Maria Silvia. Certificação, rastreabilidade e normatização. Boletim Informativo da FAEP - Federação da Agricultura do Estado do Paraná, n. 705. 2006. Disponível em: <http://www.faep.org.br>. Acesso em: 10 set. 2014.

EMPRESA BRASILEIRA DE PESQUISA AGROPECUÁRIA - EMBRAPA. A cadeia produtiva do leite e a importância da análise de impactos. Brasília, 2004. Disponível em: <http:/ / www.embrapa.br>. Acesso: 15 maio 2011. ESCRITÓRIO DE DESENVOLVIMENTO RURAL DE DRACENA - EDR-Dracena. Perfil socioeconômico do município de Dracena/São Paulo/Brasil, 2006 (Relatório da Bacia Hidrográfica do Rio Peixe/Aguapeí). 314 p.

FAO. Faostat - 1990 a 2004. Disponível em: <http:// www.fao.org >. Acesso: 3 set 2009.

FARINA, Elizabeth Maria Mercier Querido et al. Private and public milk standards in Argentina and Brazil. Food Policy, v. 30, p. 302-315, 2005.

JANK, Marcos; GALAN, Valter. Competitividade do Sistema Agroindustrial do Leite. In: FARINA, Elizabeth Maria Mercier Querido (Coord.). Competitividade da agroindústria brasileira. São Paulo: PENSA/IPEA, 1998.

KOTLER, Philip. Administração de marketing: a edição do novo milênio. 10.ed. Sao Paulo: Pearson Prentice Hall, 2000. 764p.

HILL, Terra; WESTBROOK, Roy. SWOT Analysis: It's Time for a Product Recall. Long Range Planning, v. 30, Issue 1, p. 46-52, 1997. Disponível em: <http:/ / www.sciencedirect.com/science/article/pii/S0024630196000957>. Acesso em: 3 set 2009 .

LEVANTAMENTO CENSITÁRIO DE UNIDADES DE PRODUÇÃO AGRÍCOLA DO ESTADO DE SÃO PAULO - LUPA. 2008. Disponível em: <http:/ /www. cati.sp.gov.br>. Acesso em: 4 abr. 2010.

NORDER, Luís Antonio. Mercantilização da agricultura e desenvolvimento territorial. In: SCHNEIDER, Sérgio (Org.). A diversidade da agricultura familiar. Porto Alegre, RS: UFRGS, 2006. p. 57-81.

OLIVEIRA, Djalma de Pinho Rebouças de P. R. Planejamento estratégico: conceitos, metodologia e práticas. 26. ed. São Paulo: Atlas, 2009. 376p.

PETRI, Sérgio Murilo. Modelo para apoiar a avaliação das abordagens de gestão de desempenho e sugerir aperfeiçoamentos sob a ótica construtivista. 2005. 236f. Tese (Doutorado em Engenharia de Produção) - Programa de Pós-Graduação em Engenharia de Produção da Universidade Federal de Santa Catarina, Florianópolis, SC, 2005.

PORTER, Michael. A nova estratégia. In: JÚLIO, Carlos Alberto; SALIBI NETO, José (Org.). Estratégia e planejamento. 1. ed. São Paulo: Publifolha, 2002.

SCHUBERT, Maycon Noremberg; NIEDERLE, Paulo André. A competitividade do cooperativismo de pequeno porte no sistema agroindustrial do leite no oeste catarinense. Revista IDeAS-Interface em Desenvolvimento, Agricultura e Sociedade, v. 5, n. 1, p. 188-216, 2011.

Estratégias competitivas do cooperativismo na cadeia produtiva do leite: o caso da ASCOOPER, SC. In: CONGRESSO BRASILEIRO DE ECONOMIA E SOCIOLOGIA RURAL - SOBER, 47., 26-30 jul. 2009, Porto Alegre. Anais... Porto Alegre: SOBER, 2009. Disponível em: <http://www.sober.org.br/palestra/13/104.pdf>. Acesso em: 16 set. 2014.

SEBRAE/INSTITUTO AEQUITAS. Pesquisa de qualidade aplicada à Associação de Produtores Rurais de Dracena, 2008. (disponível em relatórios manuais).

VERDEJO, Miguel Expósito. Diagnóstico Rural Participativo. Brasília: MDA/Secretaria da Agricultura Familiar, 2006. p.65.

WRIGHT, Peter; KROLL, Mark J.; PARNELL, John. Administração estratégica: conceitos. 1. ed. São Paulo: Atlas, 2000. 440p.

YIN, Robert. Case Study research. Beverly Hills, C.A: Sage Publications, 1984. 116p. 